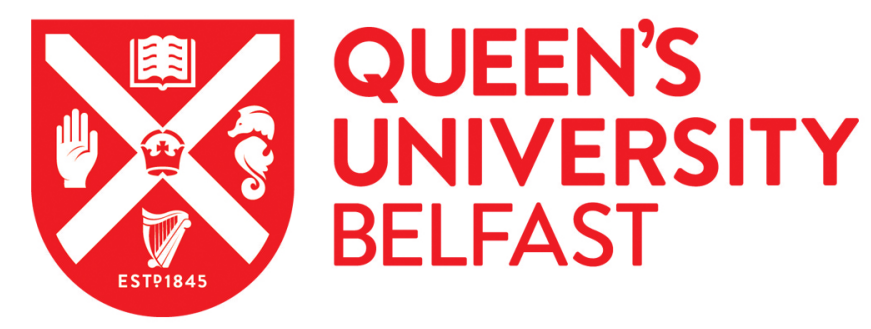

\title{
Immune modulation in advanced radiotherapies: Targeting out-of-field effects
}

Hanna, G. G., Coyle, V. M., \& Prise, K. M. (2015). Immune modulation in advanced radiotherapies: Targeting out-of-field effects. Cancer Letters, 368(2), 246-251. https://doi.org/10.1016/j.canlet.2015.04.007

\section{Published in:}

Cancer Letters

\section{Document Version:}

Peer reviewed version

Queen's University Belfast - Research Portal:

Link to publication record in Queen's University Belfast Research Portal

\section{Publisher rights}

(c) 2015 Elsevier Ireland Ltd. This manuscript version is made available under the CC-BY-NC-ND 4.0

licensehttp://creativecommons.org/licenses/by-nc-nd/4.0/,which permits distribution and reproduction for non-commercial purposes, provided the author and source are cited.

\section{General rights}

Copyright for the publications made accessible via the Queen's University Belfast Research Portal is retained by the author(s) and / or other copyright owners and it is a condition of accessing these publications that users recognise and abide by the legal requirements associated with these rights.

Take down policy

The Research Portal is Queen's institutional repository that provides access to Queen's research output. Every effort has been made to ensure that content in the Research Portal does not infringe any person's rights, or applicable UK laws. If you discover content in the Research Portal that you believe breaches copyright or violates any law, please contact openaccess@qub.ac.uk. 


\section{TITLE PAGE}

Immune modulation in advanced radiotherapies: targeting out-offield effects

\section{Authors:}

Gerard G. Hanna, Victoria M. Coyle and Kevin M. Prise.

\section{Institution:}

Centre for Cancer Research and Cell Biology

Queen's University of Belfast.

95 Lisburn Road

Belfast

N. Ireland, UK.

BT9 7AE

\section{Corresponding Author:}

Dr Gerard G. Hanna

Centre for Cancer Research and Cell Biology, Queen's University of Belfast, 95 Lisburn Road, Belfast, BT9 7AE.

Email: g.hanna@qub.ac.uk

Keywords: Immunotherapy; Abscopal Effect; Radiotherapy; Stereotactic: SABR

Word Count: $\quad 3317$ (excluding abstract and references)

Abstract Word Count: 193

Number of figures: $\quad 1$

Number of Tables: $\quad 3$ 


\section{ABSTRACT:}

By virtue of being a localized treatment modality, radiotherapy is unable to deliver a tumoricidal radiation dose to tissues outside of the irradiated field. Ionizing radiation may result in the radiation damage mediated by a bystander like effect away from the irradiated field, but this response is likely to be modest when radiotherapy is the sole treatment modality. Over the last decade there has been a re-emergence of immune modulating therapies as an anti-cancer treatment. Clinical benefits from vaccines have on the whole been largely disappointing, but greater response rates have been observed from the immune checkpoint modulators. A clinical benefit of using such agents has been shown in disease sites such as melanoma and nonsmall cell lung cancer. There is growing pre-clinical data and a number of case reports which suggest the presence of abscopal effects when radiotherapy is delivered during co-administration with immune checkpoint inhibitors, suggesting that this combination may lead to an enhanced tumor response outside of the primary treatment field. In this review, the mechanisms of such an enhanced out-of-field tumor response, the potential clinical utilities, the optimal radiotherapy delivery and considerations for clinical follow-up following treatment are discussed. 


\section{MAIN MANUSCRIPT}

\section{Introduction:}

In the last decade technological advances have permitted more accurate delivery of radiotherapy to target sites within the body, which reduces damage to surrounding normal tissue and allows radiotherapy dose escalation to maximize curability [1]. High dose, high precision and hence highly localized radiotherapy to tumor sites outside of the brain is known as stereotactic ablative body radiotherapy (SABR) [2]. SABR has been used to treat primary lung cancer with comparable control rates to surgery $[3,4]$. SABR is also used in the treatment of oligometastatic disease, where a patient has only a small number of metastatic sites are detected by conventional imaging [5]. As the name suggests, SABR delivers high dose, hypofractionated treatment and hence an ablative dose. For example, in the treatment of early stage lung cancer, regimens of 54 to 60 Gy in 3 fractions are delivered in just over a week which is in stark contrast to a standard dose of 60 to 66 Gy delivered in 30 to 33 fractions over 6 weeks [6]. When delivered with consideration for the tolerance of adjacent normal tissues SABR treatments are relatively free from significant toxicity or side-effects [6]. However, in the high dose region the ablative dose (e.g. for a patient receiving 54 Gy in 3 fractions with a maximum dose of up to $130 \%$ within the target volume, will in effect receive a biologically equivalent dose (BED) of up to 227 Gy, assuming an $\alpha / \beta$ radio of 10 ) leads to intense radiation damage and hence a significant tissue response with an associated immune response [7]. This immune response can be observed clinically in lung SABR treatments as pneumonitis transforming into fibrosis in the surrounding normal lung [8]. Although this immune response to radiation is clearly undesirable, it may be possible to harness this effect and use it to target cancer cells not irradiated within the primary tumor. 
In conjunction with the recent advances in radiotherapy delivery, over the last decade there has also been a greater understanding of the immune response to malignancy which has led to the development of a number of immune modulating agents $[9,10]$. Agents such as the immune checkpoint modulators have been shown to lead to regression of a number of solid malignancies and in some cases, a prolonged complete response to treatment has been observed [11]. In addition to this, there is growing pre-clinical data and a growing number of case reports which suggest the presence of abscopal effects when radiotherapy is delivered during coadministration with immune checkpoint inhibitors [12-15]. In the abscopal effect, an enhanced tumor response in disease locations which are outside of the primary treatment field and which have not received any radiation dose is observed $[12,16]$. It is suggested that the ablative nature of radiotherapy treatment leads to an immune response which can be augmented by immune modulating agents [17]. The underlying cellular mechanisms driving these out-of-field responses is still poorly understood but a greater mechanistic understanding could provide significant therapeutic opportunities. One area of potential clinical use of the combination of SABR and immune modulating agents is in the setting of oligometastatic disease [18]. The term oligometastatic, initially suggested by Hellman and Wecchselman, describes the presence of a limited number of metastatic sites of disease, usually less than 6 in number [19]. If an oligometastatic state is in existence, the implication is that is there are no viable micrometatases and that all the metastases that are present have declared themselves [20]. Hence eradication of the oligometastases should lead to long term cure. In this setting the potential of enhanced in-field may lead to an increased chance of long term control and even if a patient's disease is 
not truly oligometastatic and if there are clinically undetectable metastases elsewhere, immune mediated out of field responses may prevent progression of nonirradiated undetectable metastasis and may led to an increased chance of a complete response. This review considers possible mechanisms of such an enhanced out of field tumor response, the potential clinical utilities, optimal radiotherapy delivery, the timing of immune modulation and any considerations for clinical follow-up after treatment.

\section{The immune response to malignancy}

It has been shown that the immune system can detect and respond to the presence of malignant cells $[10,21]$. The immune response to cancer can be activated by the presence of antibodies to antigens on malignant cells, from tumor specific T-cells and tumor infiltrating lymphocytes [22-24]. It has been noted that in some cancers, the presence of tumor infiltrating immune cells correlates with clinical outcome [25]. Although the immune system may mount a response to cells which have undergone malignant transformation, in order to survive and proliferate tumors must develop the ability to evade surveillance and control by the host immune system [26]. Cancers use a variety of mechanisms to evade the immune system which include inhibition of tumor antigen presentation, secretion of immunosuppressive cytokines, recruitment of immunosuppressive cell types and inhibition of attack by immune cells [21, 27]. This ability to avoid immune destruction has been recently described as one of the new updated hallmarks of cancer [28]. 


\section{Immunotherapeutic approaches in the treatment of cancer}

Evasion of the immune system by cancer is essential to the process carcinogenesis, tumor development and metastasis, but modulation of the immune system may also be a potential therapeutic strategy. Immunotherapeutic strategies can be considered as either active or passive. Passive approaches involved the use of exogenous effectors of an immune response such as with humoral anti-tumor antibodies (e.g. Trastuzumab with targets and binds to the extra-cellular domain of the HER-2/neu receptor which interferes with receptor function and expression) or by a cellular adoptive approach such as with allogeneic transplantation [29]. Active approaches include non-specific immune modulation, therapeutic vaccines, modulation of T-cell function and oncolytic viruses. Examples of these are shown in table 1 [30-48].

Non-specific immune stimulation has been in routine clinical use for over a decade with the use of Interferon- $\alpha$ and interleukin-2 in the treatment of diseases such as melanoma and renal cell carcinoma. These agents act by modulating the immune system rather than by a direct cytotoxic effect [30]. However, as the name suggests, these agents are non-specific and produce significant side-effects, such as fatigue and fever, with only modest clinical benefit [31, 32, 49]. In contrast vaccine therapy is highly specific with the immune response targeted only to tumor antigens. Vaccine therapy can be directed against whole cells or directed to specific tumor antigens [50]. Despite early positive signals of response, larger studies of vaccine therapy both in the palliative or adjuvant setting have been on the whole disappointing and it is likely that vaccine therapy alone will not be efficacious strategy in anti-cancer treatment [51-53]. Oncolytic viruses have a dual mode of action. Viruses such as Talimogene laherparepvec are activated only in the malignant cell of interest [48]. 
When activated these viruses are directly cytotoxic to the malignant cell infected but they also trigger an immune response to the malignant cell, causing antigen presentation of components of the infected malignant cell and thus recognition of the malignant cell is changed and it becomes an immune target.

Of emerging clinical interest are agents which modulate T-cell function. It has been shown that tumors can evade and then escape the immune system by producing immunosuppressive cytokines, such as interferon- $\square$ (IFN $\square$ ) either from the tumor cells directly or from cells within in the tumor microenvironment [54, 55]. These immunosuppressive cytokines lead to T-cell inactivation and hence a loss of immune response. A number of immune checkpoint inhibitors such as the anti-CTL antigen-4 (CTLA-4) or anti-programmed death-1 (PD-1) antibodies which inhibit these cytokines by a number of mechanisms have been used in clinical trials and some of the agents are listed in table $1[41,44]$. CTLA-4 is crucial in maintaining tolerance to self-antigens, hence preventing auto-immune disease and is a master regulator of $\mathrm{T}$ cell activation [56]. In malignancy and in the milieu of the tumor micro-environment CTLA-4 acts to reduce or inactivate the T-Cell response. In a normal immune response the T-cell receptor will bind to a presented antigen. In order for the T-cell to be activated CD28 must also bind to CD80 and CD86 on the surface of the antigen presenting cell to provide a co-stimulation of the T-cell. CTLA-4 competitively competes with the CD28/CD80/CD86 complex and in the tumor micro-environment where CD80 and CD86 are depleted, the result is T-cell inhibition mediated by CTLA-4 [56]. CTLA-4 is also expressed on CD4+ regulatory T cells which are also known as (Tregs). On Tregs CTLA-4 induces the production of the highly suppressive cytokine transforming growth factor beta which also acts to down- 
regulate T-cell function [57]. Thus CTLA-4 has a key role in reducing T-cell mediated immunity. Mono-clonal antibodies against CTLA-4 such as ipilimumab have been shown to be effective as single agents, with some durable clinical responses noted [41].

PD-1 is an inhibitory receptor expressed on T-cells whose normal function is crucial for preventing the development of autoimmune disease [58]. PD-1 may not have an overarching role in the normal immune response but it is thought that the function of PD-1 is to limit normal tissue damage in the presence of inflammation [59]. Two main ligands of PD-1 (PD-L1 and PD-L2) have been identified and these bind to PD-1 to inhibit T-cell function and up-regulation of these, within tumours, is common and is associated with a poor prognosis [60]. A number of PD-L1 and PD-L2 inhibitors have been shown to be effective across a range of tumor sites [44, 45]. This mechanism is illustrated in figure 1 and a summary of the currently available PD-1 inhibitors is shown in table $2[28,45-47,61-63]$.

Why the combination of immunotherapy with radiotherapy may be synergistic. Out of field effects following radiotherapy treatment, mediated by a number of different mechanisms, have been previously described [64]. One of the clinical manifestations of this, the abscopal effect, has been described in a number of case reports [65-68]. As stated earlier, abscopal effects have been reported when radiotherapy has been delivered to patients on immune modulating agents $[12,15$, 69]. In a seminal experiment by Demaria et al, radiation responses were compared between immunocompetent and T-cell deficient (nude) mice each with two tumors. Both sets of mice received irradiation to one tumor only, both sets demonstrated a 
retardation of growth in the irradiated tumor but only the immunocompetent mice had growth retardation in the non-irradiated tumor [70]. The authors went onto hypothesize that the abscopal effect must be in some part immune mediated and is T-cell dependent [71].

So might the combination of ionizing radiation and immune modulation be synergistic? The accepted key mechanism of cell death following radiotherapy is that radiation induced damage mediated by free radicals to cellular structures, in particular the DNA and the production of DNA double-strand breaks, which in turn leads to apoptosis when the damage is not repaired [72, 73]. However there is longstanding evidence that radiation exposure can lead to non-targeted effects, specifically bystander signalling mediated by cytokine release [64]. These have been classified into three distinct categories [74]. Firstly, classical bystander effects where irradiated cells signal with non-irradiated cells within a tissue, for example under conditions of localised irradiation including very low dose exposures. Secondly, abscopal effects, as described above, where responses at sites outside the treatment field are observed. A third category have been termed cohort effects where variable dose regions are observed typically within tumours receiving advanced radiotherapies where intercellular signalling leading to out-of-field effects can also play a role $[75,76]$. However, in all three of these categories, it is also thought that radiotherapy, through direct cellular damage, leads to antigen presentation and may trigger an immune response [17]. Key to this process is the involvement of the tumor micro-environment $[77,78]$. Ionizing radiation induces key chemokines, such as IFN- $\square$, CXCL9, CXCL10, and CXCL16, which attract effector T cells to the tumor by increasing T-cell motility and vascular permeability to T-cells 
[79-81]. Furthermore, following radiation, tumor cells may up-regulate many key cell surface ligands that increase the probability of antigen presentation to cytotoxic Tcells in a process known as immunogenic modulation [82]. Other elements of immunogenic modulation include changes in the mechanism of antigen presentation and translocation of calreticulin to the cell surface [82-85]. It has also been suggested that modulated radiation induced immune responses may show a long duration of effect [86]. Thus the combination of radiotherapy and immune modulation represents a possible new paradigm shift in the management of advanced malignancy [87].

Following the US Food and Drug Administration approval of Sipuleucel-T for the treatment of advanced hormone resistant prostate cancer there is has been a reemergence of interest in vaccine therapy [35]. A number of pre-clinical and clinical studies have examined the effects of combining radiotherapy with vaccines, the rationale behind this combination is that the immune response mediated by radiotherapy may enhance the efficacy of the vaccine or vice versa. A range of vaccine types have been used in combination with radiotherapy and examples of the human studies are listed in table 3 [88-93]. At present vaccine therapy with radiotherapy is confined to early phase studies across a range of tumor types such as lung cancer [94]. Furthermore, the optimal radiotherapy dose and scheduling of vaccine delivery around radiotherapy will likely depend on the vaccine and tumor type and this will require further clinical investigation [95].

A number of case reports of abscopal effects with the combination of CTLA-4 inhibitors and radiotherapy have led to interest in this combination [12, 69]. However 
there are also case reports of immune mediated abscopal responses in patients who have not responded to CTLA-4 inhibitors, hence the mechanism of this interaction is not clear [15]. Agents such as Ipilumimab in these settings used as monotherapy may not be entirely effective in triggering an immune response against the cancer. But, when radiotherapy is delivered, the subsequent immune response in addition to the CTLA-4 inhibitor is sufficient to trigger a T-cell mediated response to the malignant cells. Of note, both intra and inter-personal factors, both in terms of tumor heterogeneity and immune programming most probably will be determinants of differential responses. Of particular interest is the combination of anti-PD-1 antibodies with radiotherapy. The unique role of PD-1 in down-regulating the immune response to inflammation suggests that turning off this pathway in combination with radiotherapy delivery may lead to an enhanced response beyond that seen with antiPD-1 therapy alone [59]. In a mouse glioma model, the combination of a constructed anti-PD-1 antibody and stereotactic radiotherapy leads to long term survival supporting the efficacy of this combination [13]. In another murine model of breast and colorectal carcinoma, enhanced tumor control was seen with the combination of radiotherapy and an anti-PD-1 antibody [14].

\section{Is radiation dose and fractionation important?}

Considering the variables in radiotherapy delivery along with immune modulating agents, it may be hypothesized that higher doses of radiotherapy may lead to increased DNA damage and hence an enhanced immune response. In preclinical studies, low dose irradiation has been shown to increase T-cell migration into the irradiated field [96]. It has also been suggested that radiotherapy doses from as low as 2 Gy but up to 20 Gy may be sufficient to trigger immunogenic cell death [17]. In 
the case reports of an abscopal effect with the combination of radiotherapy and ipilumimab, hypofractionated doses of 30 Gy delivered in 5 fractions and 28.5 Gy delivered in 3 fractions were used but these do not represent as high a BED as to those seen in SABR (BED of $48 \mathrm{~Gy}$, assuming an $\alpha / \beta$ ratio of 10 for the tumor as compared of a BED of 151 Gy with a SABR type dose of 54 Gy delivered in 3 fractions) $[12,15]$. Given the high local and distant control rates in these reports, might immunotherapy provide some compensation for the lower radiation doses delivered? However, in the era of high local control with typical SABR doses, maintaining good local control is still a key goal and future clinical studies of radiotherapy combinations with immunotherapy in oligometastatic disease are likely to use SABR type doses to avoid compromise on local control. It has been shown that fractionated but not single dose radiotherapy induces an immune mediated abscopal effect; hence if SABR doses are to be used, they should be fractionated to some extent [97]. What is almost certain is that the immune effect of radiotherapy is very likely to depend on the tumor type and immune modulation used. Although differences in radiotherapy dose, fractionation regimens used and the nature of radiation delivery (photons as comparable to particle beams) will be factors in engendering an abscopal response, where possible and for the purposes of designing high quality controlled studies, radiotherapy delivery should be standardized where possible [98].

\section{Issues for clinical follow-up in the setting of immune modulation}

Single agent immune modulating studies have poor clinical response rates. For example in a study of ipilumimab in melanoma the best overall response (complete or partial response) rate was $10.9 \%$ [41]. However, a minority of patients achieve 
long-term disease control often requiring several months to demonstrate an objective response. This slow to emerge, but prolonged and durable effect of immunotherapy is a feature of many of the clinical studies [11]. Hence in any studies examined the combination of immune modulating agents must undertake careful and prolonged follow-up. Furthermore, early termination of such studies on the grounds of futility must not be at the expense of missing an important late effect.

\section{Conclusions}

Radiotherapy has powerful effect on the tumor micro-environment with the potential to reverse the immunosuppressive state present in malignancy. Combinations of immune modulating agents and radiotherapy look promising both in over-coming local resistance to radiotherapy and in generating an out of field or abscopal effect. Future studies of the many possible combinations of immune modulating agents and radiotherapy are urgently needed to explore the potentially powerful abscopal effects reported in animal models and case reports to date. If the early promise from these studies is translated into a larger scale clinical benefit, then the combination of radiotherapy and immunotherapy may truly represent a paradigm shift in oligometastatic disease. 


\section{Acknowledgements}

The authors are grateful to Cancer Research UK (Grants C1513/A707 and C212/A11342) for supporting their work. 


\section{LIST OF TABLES}

Table 1: Examples of Active Immunotherapeutic Approaches

Table 2: Summary of PD-1 and PD-L1 checkpoint inhibitors in clinical development

Table 3: Vaccines which have been delivered in conjunction with radiotherapy in human subjects

\section{FIGURE CAPTIONS}

\section{Figure 1:}

This schema illustrates the 3 various scenarios in a T-cell response to a malignant cell:

A. This represents the normal activated T-cell response to antigen presenting cell or in the case of malignancy, a tumor cell. Following antigen presentation, the binding of CD-28 with CD-80 /CD-86 leads to T-cell activation and which in turn leads to increased T-Cell proliferation and cytokine production.

B. This represent immune escape by the tumor in which the tumor derived PD-L1 binds to PD-D on the T-cell leading to a suppressed T-cell Response with decreased T-cell Proliferation and cytokine production.

C. Illustrates the impact of PD-1 ligand inhibition and thus restored T-cell function. 


\section{REFERENCES:}

1. Verellen D, De Ridder M, Linthout $\mathrm{N}$ et al. Innovations in image-guided radiotherapy. Nat Rev Cancer 2007; 7: 949-960.

2. Jain $\mathrm{P}$, Baker $\mathrm{A}$, Distefano $\mathrm{G}$ et al. Stereotactic ablative radiotherapy in the UK: current status and developments. Br J Radiol 2013; 86: 20130331.

3. Lagerwaard FJ, Verstegen NE, Haasbeek CJ et al. Outcomes of stereotactic ablative radiotherapy in patients with potentially operable stage I non-small cell lung cancer. Int J Radiat Oncol Biol Phys 2012; 83: 348-353.

4. Onishi $\mathrm{H}$, Shirato $\mathrm{H}$, Nagata $\mathrm{Y}$ et al. Stereotactic body radiotherapy (SBRT) for operable stage I non-small-cell lung cancer: can SBRT be comparable to surgery? Int J Radiat Oncol Biol Phys 2011; 81: $1352-1358$

5. Tree AC, Khoo VS, Eeles RA et al. Stereotactic body radiotherapy for oligometastases. Lancet Oncol 2013; 14: e28-37.

6. Palma D, Lagerwaard F, Rodrigues $G$ et al. Curative treatment of Stage I non-small-cell lung cancer in patients with severe COPD: stereotactic radiotherapy outcomes and systematic review. Int J Radiat Oncol Biol Phys 2012; 82: 1149-1156.

7. Brown JM, Carlson DJ, Brenner DJ. The tumor radiobiology of SRS and SBRT: are more than the 5 Rs involved? Int J Radiat Oncol Biol Phys 2014; 88: 254-262.

8. Diot Q, Kavanagh B, Schefter T et al. Regional normal lung tissue density changes in patients treated with stereotactic body radiation therapy for lung tumors. Int J Radiat Oncol Biol Phys 2012; 84: 1024-1030.

9. Drake CG, Jaffee E, Pardoll DM. Mechanisms of immune evasion by tumors. Adv Immunol 2006; 90: 51-81.

10. Finn OJ. Immuno-oncology: understanding the function and dysfunction of the immune system in cancer. Ann Oncol 2012; 23 Suppl 8: viii6-9.

11. Postow MA, Callahan MK, Wolchok JD. The Antitumor Immunity of Ipilimumab: (T-cell) Memories to Last a Lifetime? Clinical Cancer Research 2012; 18: 1821-1823.

12. Postow MA, Callahan MK, Barker CA et al. Immunologic correlates of the abscopal effect in a patient with melanoma. N Engl J Med 2012; 366: 925-931.

13. Zeng J, See AP, Phallen J et al. Anti-PD-1 Blockade and Stereotactic Radiation Produce Long-Term Survival in Mice With Intracranial Gliomas. International Journal of Radiation Oncology*Biology*Physics 2013; 86: 343-349.

14. Deng L, Liang H, Burnette B et al. Irradiation and anti-PD-L1 treatment synergistically promote antitumor immunity in mice. The Journal of Clinical Investigation 2014; 124: 687-695.

15. Golden EB, Demaria S, Schiff PB et al. An Abscopal Response to Radiation and Ipilimumab in a Patient with Metastatic Non-Small Cell Lung Cancer. Cancer Immunology Research 2013; 1: 365-372.

16. Mole RH. Whole body irradiation; radiobiology or medicine? Br J Radiol 1953; 26: 234-241.

17. Golden EB, Frances D, Pellicciotta I et al. Radiation fosters dose-dependent and chemotherapy-induced immunogenic cell death. Oncolmmunology 2014; 3: e28518.

18. Ashworth A, Rodrigues G Fau - Boldt G, Boldt G Fau - Palma D, Palma D. Is there an oligometastatic state in non-small cell lung cancer? A systematic review of the literature.

19. Hellman S, Weichselbaum RR. Oligometastases. J Clin Oncol 1995; 13: 8-10.

20. Macdermed DM, Weichselbaum RR, Salama JK. A rationale for the targeted treatment of oligometastases with radiotherapy. J Surg Oncol 2008; 98: 202-206.

21. Vesely MD, Kershaw MH, Schreiber RD, Smyth MJ. Natural innate and adaptive immunity to cancer. Annu Rev Immunol 2011; 29: 235-271.

22. Reuschenbach M, von Knebel Doeberitz M, Wentzensen N. A systematic review of humoral immune responses against tumor antigens. Cancer Immunol Immunother 2009; 58: 1535-1544.

23. Godet $\mathrm{Y}$, Fabre $\mathrm{E}$, Dosset $\mathrm{M}$ et al. Analysis of spontaneous tumor-specific CD4 T-cell immunity in lung cancer using promiscuous HLA-DR telomerase-derived epitopes: potential synergistic effect with chemotherapy response. Clin Cancer Res 2012; 18: 2943-2953.

24. Mlecnik B, Bindea G, Pages F, Galon J. Tumor immunosurveillance in human cancers. Cancer Metastasis Rev 2011; 30: 5-12.

25. Galon J, Costes A, Sanchez-Cabo F et al. Type, density, and location of immune cells within human colorectal tumors predict clinical outcome. Science 2006; 313: 1960-1964.

26. Dunn GP, Old LJ, Schreiber RD. The immunobiology of cancer immunosurveillance and immunoediting. Immunity 2004; 21 : 137-148. 
27. Kerkar SP, Restifo NP. Cellular constituents of immune escape within the tumor microenvironment. Cancer Res 2012; 72: 3125-3130.

28. Hanahan D, Weinberg RA. Hallmarks of cancer: the next generation. Cell 2011; 144: 646674.

29. Hudis CA. Trastuzumab - Mechanism of Action and Use in Clinical Practice. New England Journal of Medicine 2007; 357: 39-51.

30. Davar D, Tarhini AA, Kirkwood JM. Adjuvant therapy for melanoma. Cancer J 2012; 18: 192202.

31. Amin A, White RL, Jr. High-dose interleukin-2: is it still indicated for melanoma and RCC in an era of targeted therapies? Oncology (Williston Park) 2013; 27: 680-691.

32. Mocellin S, Lens MB, Pasquali S et al. Interferon alpha for the adjuvant treatment of cutaneous melanoma. Cochrane Database Syst Rev 2013; 6: Cd008955.

33. Benson DM, Jr., Hofmeister CC, Padmanabhan S et al. A phase 1 trial of the anti-KIR antibody IPH2101 in patients with relapsed/refractory multiple myeloma. Blood 2012; 120: 4324-4333.

34. Prendergast GC, Smith C, Thomas S et al. Indoleamine 2,3-dioxygenase pathways of pathogenic inflammation and immune escape in cancer. Cancer Immunol Immunother 2014; 63: 721735.

35. Kantoff PW, Higano CS, Shore ND et al. Sipuleucel-T Immunotherapy for CastrationResistant Prostate Cancer. New England Journal of Medicine 2010; 363: 411-422.

36. Kruit WH, Suciu S, Dreno B et al. Selection of immunostimulant AS15 for active immunization with MAGE-A3 protein: results of a randomized phase II study of the European Organisation for Research and Treatment of Cancer Melanoma Group in Metastatic Melanoma. J Clin Oncol 2013; 31: 2413-2420.

37. Vazquez AM, Hernandez AM, Macias A et al. Racotumomab: an anti-idiotype vaccine related to N-glycolyl-containing gangliosides - preclinical and clinical data. Front Oncol 2012; 2: 150.

38. Rossi GR, Mautino MR, Awwad DZ et al. Allogeneic melanoma vaccine expressing alphaGal epitopes induces antitumor immunity to autologous antigens in mice without signs of toxicity. $J$ Immunother 2008; 31: 545-554.

39. Kohrt HE, Colevas AD, Houot R et al. Targeting CD137 enhances the efficacy of cetuximab. J Clin Invest 2014; 124: 2668-2682.

40. Shi X, Dornan D. To respond or not to respond to CD40 agonism: That is the prediction. Oncoimmunology 2012; 1: 83-85.

41. Hodi FS, O'Day SJ, McDermott DF et al. Improved Survival with Ipilimumab in Patients with Metastatic Melanoma. New England Journal of Medicine 2010; 363: 711-723.

42. Woo SR, Turnis ME, Goldberg MV et al. Immune inhibitory molecules LAG-3 and PD-1 synergistically regulate T-cell function to promote tumoral immune escape. Cancer Res 2012; 72: 917-927.

43. Weinberg AD, Morris NP, Kovacsovics-Bankowski M et al. Science gone translational: the OX40 agonist story. Immunol Rev 2011; 244: 218-231.

44. Topalian SL, Hodi FS, Brahmer JR et al. Safety, activity, and immune correlates of anti-PD-1 antibody in cancer. N Engl J Med 2012; 366: 2443-2454.

45. Brahmer JR, Tykodi SS, Chow LQM et al. Safety and Activity of Anti-PD-L1 Antibody in Patients with Advanced Cancer. New England Journal of Medicine 2012; 366: 2455-2465.

46. Robert C, Ribas A, Wolchok JD et al. Anti-programmed-death-receptor-1 treatment with pembrolizumab in ipilimumab-refractory advanced melanoma: a randomised dose-comparison cohort of a phase 1 trial. Lancet 2014; 384: 1109-1117.

47. Robert C, Long GV, Brady B et al. Nivolumab in Previously Untreated Melanoma without BRAF Mutation. N Engl J Med 2014.

48. Pol J, Bloy N, Obrist $F$ et al. Trial Watch:: Oncolytic viruses for cancer therapy. Oncoimmunology 2014; 3: e28694.

49. Tarhini AA, Gogas H, Kirkwood JM. IFN-alpha in the treatment of melanoma. J Immunol 2012; 189: 3789-3793.

50. Mellstedt H, Vansteenkiste J, Thatcher N. Vaccines for the treatment of non-small cell lung cancer: investigational approaches and clinical experience. Lung Cancer 2011; 73: 11-17.

51. Vansteenkiste J, Zielinski M, Linder A et al. Adjuvant MAGE-A3 immunotherapy in resected non-small-cell lung cancer: phase II randomized study results. J Clin Oncol 2013; 31: 2396-2403.

52. ESMO. FDA backs continued study of belagenpumatucel-L for subgroups of patients based on data from phase III STOP trial. In. http://www.esmo.org/: ESMO 2003.

53. Eggermont AM. Immunotherapy: Vaccine trials in melanoma -- time for reflection. Nat Rev Clin Oncol 2009; 6: 256-258. 
54. Gajewski TF, Schreiber H, Fu Y-X. Innate and adaptive immune cells in the tumor microenvironment. Nat Immunol 2013; 14: 1014-1022.

55. Spranger S, Spaapen RM, Zha Y et al. Up-regulation of PD-L1, IDO, and T(regs) in the melanoma tumor microenvironment is driven by CD8(+) T cells. Sci Transl Med 2013; 5: 200 ra116.

56. Collins AV, Brodie DW, Gilbert RJC et al. The Interaction Properties of Costimulatory Molecules Revisited. Immunity 2002; 17: 201-210.

57. Chen W, Jin W, Wahl SM. Engagement of cytotoxic T lymphocyte-associated antigen 4 (CTLA-4) induces transforming growth factor beta (TGF-beta) production by murine CD4(+) T cells. J Exp Med 1998; 188: 1849-1857.

58. Wang J, Yoshida T, Nakaki F et al. Establishment of NOD-Pdcd1-/- mice as an efficient animal model of type I diabetes. Proceedings of the National Academy of Sciences of the United States of America 2005; 102: 11823-11828.

59. Topalian SL, Drake CG, Pardoll DM. Targeting the PD-1/B7-H1(PD-L1) pathway to activate anti-tumor immunity. Current Opinion in Immunology 2012; 24: 207-212.

60. Zhang Y, Wang L, Li Y et al. Protein expression of programmed death 1 ligand 1 and ligand 2 independently predict poor prognosis in surgically resected lung adenocarcinoma. OncoTargets and Therapy 2014; 7: 567-573.

61. Momtaz P, Postow MA. Immunologic checkpoints in cancer therapy: focus on the programmed death-1 (PD-1) receptor pathway. Pharmgenomics Pers Med 2014; 7: 357-365.

62. Berger R, Rotem-Yehudar R, Slama G et al. Phase I Safety and Pharmacokinetic Study of CT-011, a Humanized Antibody Interacting with PD-1, in Patients with Advanced Hematologic Malignancies. Clinical Cancer Research 2008; 14: 3044-3051.

63. Herbst RS, Soria JC, Kowanetz M et al. Predictive correlates of response to the anti-PD-L1 antibody MPDL3280A in cancer patients. Nature 2014; 515: 563-567.

64. Prise KM, O'Sullivan JM. Radiation-induced bystander signalling in cancer therapy. Nat Rev Cancer 2009; 9: 351-360.

65. Siva S, Callahan J, MacManus MP et al. Abscopal [corrected] effects after conventional and stereotactic lung irradiation of non-small-cell lung cancer. J Thorac Oncol 2013; 8: e71-72.

66. Antoniades J, Brady LW, Lightfoot DA. Lymphangiographic demonstration of the abscopal effect in patients with malignant lymphomas. Int J Radiat Oncol Biol Phys 1977; 2: 141-147.

67. Ohba K, Omagari K, Nakamura T et al. Abscopal regression of hepatocellular carcinoma after radiotherapy for bone metastasis. Gut 1998; 43: 575-577.

68. Ehlers G, Fridman M. Abscopal effect of radiation in papillary adenocarcinoma. Br $\mathrm{J}$ Radiol 1973; 46: 220-222.

69. Stamell EF, Wolchok JD, Gnjatic S et al. The abscopal effect associated with a systemic antimelanoma immune response. Int J Radiat Oncol Biol Phys 2013; 85: 293-295.

70. Demaria $\mathrm{S}, \mathrm{Ng} \mathrm{B}$, Devitt $\mathrm{ML}$ et al. Ionizing radiation inhibition of distant untreated tumors (abscopal effect) is immune mediated. International Journal of Radiation Oncology*Biology ${ }^{\star}$ Physics 2004; 58: 862-870.

71. Formenti SC, Demaria S. Systemic effects of local radiotherapy. The Lancet Oncology 2009; 10: $718-726$

72. Prise KM, Schettino G, Folkard M, Held KD. New insights on cell death from radiation exposure. The Lancet Oncology 2005; 6: 520-528.

73. Eriksson D, Stigbrand T. Radiation-induced cell death mechanisms. Tumor Biology 2010; 31 : 363-372.

74. Blyth BJ, Sykes PJ. Radiation-induced bystander effects: what are they, and how relevant are they to human radiation exposures? Radiat Res 2011; 176: 139-157.

75. Butterworth KT, McGarry CK, Trainor C et al. Out-of-field cell survival following exposure to intensity-modulated radiation fields. Int J Radiat Oncol Biol Phys 2011; 79: 1516-1522.

76. McMahon SJ, McGarry CK, Butterworth KT et al. Implications of intercellular signaling for radiation therapy: a theoretical dose-planning study. Int J Radiat Oncol Biol Phys 2013; 87: 11481154.

77. Demaria S, Formenti SC. Sensors of ionizing radiation effects on the immunological microenvironment of cancer. International Journal of Radiation Biology 2007; 83: 819-825.

78. Rodel F, Frey B, Multhoff G, Gaipl U. Contribution of the immune system to bystander and non-targeted effects of ionizing radiation. Cancer Lett 2015; 356: 105-113.

79. Lugade AA, Sorensen EW, Gerber SA et al. Radiation-Induced IFN-y Production within the Tumor Microenvironment Influences Antitumor Immunity. The Journal of Immunology 2008; 180: 3132-3139. 
80. Lugade AA, Moran JP, Gerber SA et al. Local Radiation Therapy of B16 Melanoma Tumors Increases the Generation of Tumor Antigen-Specific Effector Cells That Traffic to the Tumor. The Journal of Immunology 2005; 174: 7516-7523.

81. Matsumura S, Demaria S. Up-regulation of the pro-inflammatory chemokine CXCL16 is a common response of tumor cells to ionizing radiation. Radiat Res 2010; 173: 418-425.

82. Kwilas AR, Donahue RN, Bernstein MB, Hodge JW. In the field: exploiting the untapped potential of immunogenic modulation by radiation in combination with immunotherapy for the treatment of cancer. Front Oncol 2012; 2: 104.

83. Makinde AY, John-Aryankalayil M, Palayoor ST et al. Radiation Survivors: Understanding and Exploiting the Phenotype following Fractionated Radiation Therapy. Molecular Cancer Research 2013; 11: 5-12.

84. Friedman EJ. Immune modulation by ionizing radiation and its implications for cancer immunotherapy. Curr Pharm Des 2002; 8: 1765-1780.

85. Janssens S, Tschopp J. Signals from within: the DNA-damage-induced NF-[kappa]B response. Cell Death Differ 2006; 13: 773-784.

86. Ifeadi V, Garnett-Benson C. Sub-lethal irradiation of human colorectal tumor cells imparts enhanced and sustained susceptibility to multiple death receptor signaling pathways. PLoS One 2012; 7: e31762.

87. Formenti SC, Demaria S. Combining Radiotherapy and Cancer Immunotherapy: A Paradigm Shift. Journal of the National Cancer Institute 2013; 105: 256-265.

88. Chi K-H, Liu S-J, Li C-P et al. Combination of Conformal Radiotherapy and Intratumoral Injection of Adoptive Dendritic Cell Immunotherapy in Refractory Hepatoma. Journal of Immunotherapy 2005; 28: 129-135.

89. Shibamoto $\mathrm{Y}$, Okamoto M, Kobayashi M et al. Immune-maximizing (IMAX) therapy for cancer: Combination of dendritic cell vaccine and intensity-modulated radiation. Mol Clin Oncol 2013; 1: 649654.

90. Gulley JL, Arlen PM, Bastian A et al. Combining a recombinant cancer vaccine with standard definitive radiotherapy in patients with localized prostate cancer. Clin Cancer Res 2005; 11: 33533362.

91. Lechleider RJ, Arlen PM, Tsang KY et al. Safety and immunologic response of a viral vaccine to prostate-specific antigen in combination with radiation therapy when metronomic-dose interleukin 2 is used as an adjuvant. Clin Cancer Res 2008; 14: 5284-5291.

92. linuma $\mathrm{H}$, Fukushima $\mathrm{R}$, Inaba $\mathrm{T}$ et al. Phase I clinical study of multiple epitope peptide vaccine combined with chemoradiation therapy in esophageal cancer patients. J Transl Med 2014; 12: 84.

93. Pancreatic Tumor Cell Vaccine (GVAX), Low Dose Cyclophosphamide, Fractionated Stereotactic Body Radiation Therapy (SBRT), and FOLFIRINOX Chemotherapy in Patients With Resected Adenocarcinoma of the Pancreas. In.

94. Sebastian M, Papachristofilou A, Weiss $C$ et al. Phase lb study evaluating a self-adjuvanted mRNA cancer vaccine (RNActive $(R))$ combined with local radiation as consolidation and maintenance treatment for patients with stage IV non-small cell lung cancer. BMC Cancer 2014; $14: 748$.

95. Chamoto K, Takeshima $T$, Wakita $D$ et al. Combination immunotherapy with radiation and CpG-based tumor vaccination for the eradication of radio- and immuno-resistant lung carcinoma cells. Cancer Sci 2009; 100: 934-939.

96. Klug $\mathrm{F}$, Prakash $\mathrm{H}$, Huber PE et al. Low-dose irradiation programs macrophage differentiation to an iNOS(+)/M1 phenotype that orchestrates effective T cell immunotherapy. Cancer Cell 2013; 24: 589-602.

97. Dewan MZ, Galloway AE, Kawashima $\mathrm{N}$ et al. Fractionated but not single-dose radiotherapy induces an immune-mediated abscopal effect when combined with anti-CTLA-4 antibody. Clin Cancer Res 2009; 15: 5379-5388.

98. Durante $\mathrm{M}$, Reppingen $\mathrm{N}$, Held KD. Immunologically augmented cancer treatment using modern radiotherapy. Trends Mol Med 2013; 19: 565-582. 
Immune modulation in advanced radiotherapies: targeting out-offield effects

\section{Conflict of interest statement:}

None of the authors have any conflict of interest to declare 


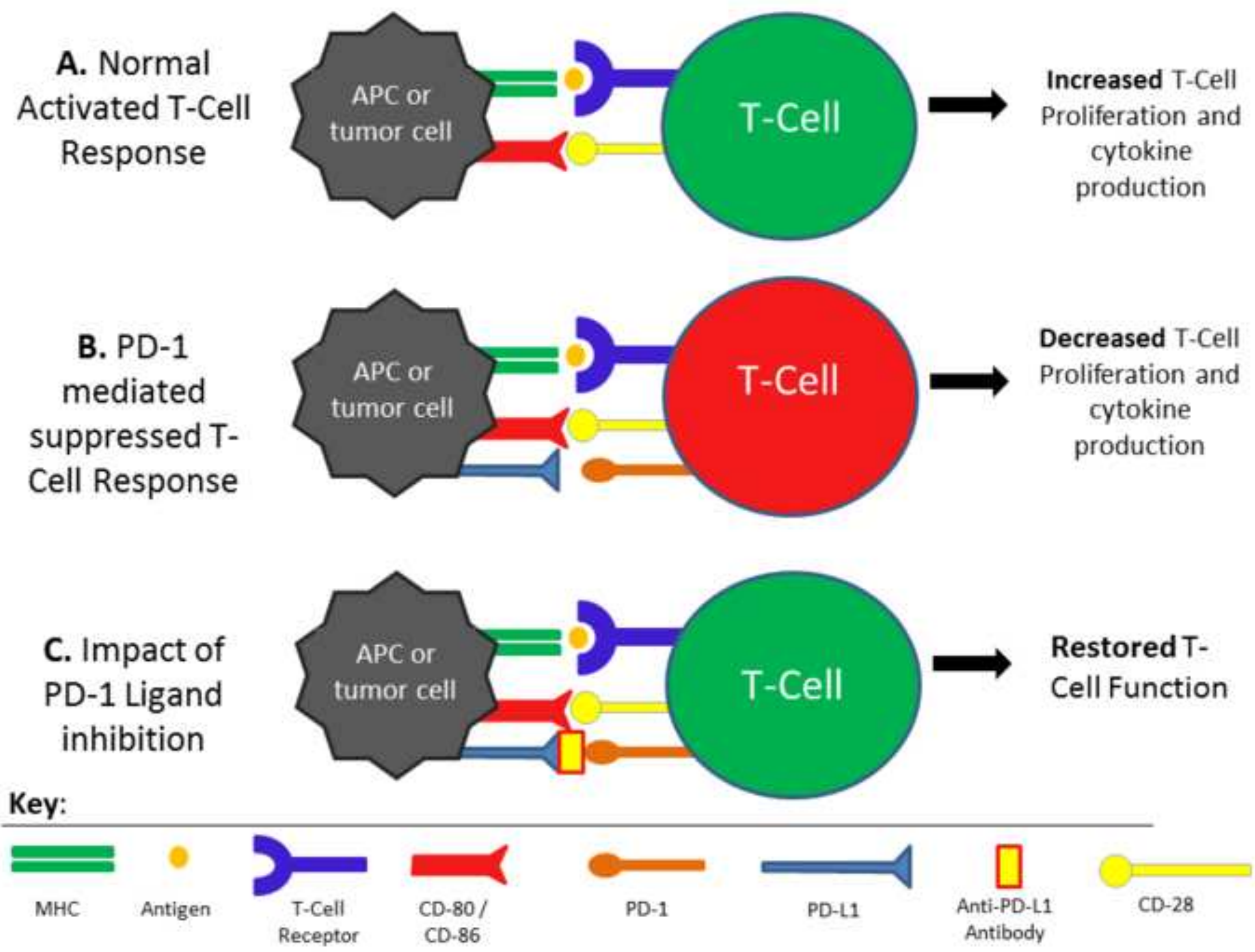




\section{Tables: Immune modulation in advanced radiotherapies: targeting out-of-field effects.}

Table 1: Examples of Active Immunotherapeutic Approaches

\begin{tabular}{|c|c|}
\hline $\begin{array}{c}\text { Non-specific } \\
\text { immune stimulation }\end{array}$ & $\begin{array}{l}\text { - } \text { Cytokines (e.g. Interleukin-2, Interferon- } \alpha \text { ) [30-32] } \\
\text { - Killer-cell immunoglobulin-like receptors antagonists [33] } \\
\text { - Indoleamine 2,3-dioxygenase (IDO) pathway inhibitors [34] }\end{array}$ \\
\hline $\begin{array}{c}\text { Therapeutic } \\
\text { vaccines }\end{array}$ & $\begin{array}{l}\text { - } \text { Sipuleucel-T (prostate carcinoma) [35] } \\
\text { - Anti-MAGE-A3 vaccine (non-small cell lung cancer and } \\
\text { others) [36] } \\
\text { - Racotumomab - anti N-glycolil (lung carcinoma, breast } \\
\text { carcinoma, melanoma) [37] } \\
\text { - Tergenpumatucel-L - (lung carcinoma) [38] }\end{array}$ \\
\hline $\begin{array}{l}\text { Modulate T-Cell } \\
\text { function }\end{array}$ & $\begin{array}{ll}\text { - } & \text { CD137 agonism [39] } \\
\text { - } & \text { CD40 agonism [40] } \\
\text { - } & \text { CTLA-4 inhibition [41] } \\
\text { - } & \text { LAG-3 inhibition [42] } \\
\text { - } & \text { OX-40 agonism [43] } \\
\text { - PD-1 inhibition [44] } \\
\text { - PD-L1 inhibition [45] } \\
\text { - } \\
\text { PD-L2 inhibition [46, 47] }\end{array}$ \\
\hline Oncolytic viruses & - Talimogene laherparepvec (T-VEC, melanoma) [48] \\
\hline
\end{tabular}


Table 2: Summary of PD-1 and PD-L1 checkpoint inhibitors in clinical development

\begin{tabular}{|c|c|c|}
\hline Agent & Classification & Mode of action \\
\hline AMP-225 [61] & Recombinant Fusion Protein & $\begin{array}{l}\text { Blocks interaction between PD-1 and B7- } \\
\qquad \mathrm{H} 1\end{array}$ \\
\hline $\begin{array}{c}\text { BMS-936559 } \\
{[45]}\end{array}$ & $\begin{array}{l}\text { Humanised anti-PD-L1 monoclonal } \\
\text { antibody }\end{array}$ & Blocks PD-L1 binding to PD-1 and CD80 \\
\hline $\begin{array}{c}\text { MEDI4736 } \\
\text { [61] }\end{array}$ & $\begin{array}{l}\text { Humanised anti-PD-L1 monoclonal } \\
\text { antibody }\end{array}$ & Blocks PD-L1 binding to PD-1 and CD80 \\
\hline $\begin{array}{c}\text { MPDL3280A } \\
\text { [63] }\end{array}$ & $\begin{array}{l}\text { Humanised anti-PD-L1 monoclonal } \\
\text { antibody }\end{array}$ & Blocks PD-L1 binding to PD-1 and CD80 \\
\hline Nivolumab [47] & $\begin{array}{l}\text { Humanised anti-PD-1 monoclonal } \\
\text { antibody }\end{array}$ & Blocks PD-1 binding to PD-L1 and PD-L2 \\
\hline $\begin{array}{c}\text { Pembrolizumab } \\
{[46]}\end{array}$ & $\begin{array}{l}\text { Humanised anti PD-1 monoclonal } \\
\text { antibody }\end{array}$ & Blocks PD-1 binding to PD-L1 and PD-L2 \\
\hline Pidilizumab [62] & $\begin{array}{l}\text { Humanised anti-PD-1 monoclonal } \\
\text { antibody }\end{array}$ & Blocks PD-1 binding to PD-L1 and PD-L2 \\
\hline
\end{tabular}


Table 3: Vaccines which have been delivered in conjunction with radiotherapy in human subjects

\begin{tabular}{|l|l|l|}
\hline Vaccine Class & Agent & Primary Tumor Type \\
\hline Dendritic & $\begin{array}{l}\text { Autologous immature dendritic } \\
\text { cells }\end{array}$ & Hepatoma [88] \\
\cline { 2 - 3 } & Autologous dendritic cells & Numerous [89] \\
\hline \multirow{2}{*}{ Viral } & Pox-based vaccine & Prostate [90] \\
\cline { 2 - 3 } & $\begin{array}{l}\text { Smallpox and fowlpox vaccine } \\
\text { targeting carcinoembryonic } \\
\text { antigen (CEA) }\end{array}$ & Colorectal [91] \\
\hline Protein & Multiple peptide based vaccine & Esophageal [92] \\
\hline Whole Cell & $\begin{array}{l}\text { Pancreatic Tumor Cell Vaccine } \\
\text { (GVAX) }\end{array}$ & Pancreas [93] \\
\hline Nucleic Acid & None at present & N/A \\
\hline
\end{tabular}

